\title{
Notes
}

\section{The Panopticon Revisited: The Problem of Monitoring Private Prisons}

\author{
James Theodore Gentry
}

For a governmental entity squeezed by budgetary constraints, delegation of costly tasks to a private contractor that promises to perform them for less is an appealing option. Recently, public agencies responsible for our prison systems have rediscovered the allure of this sort of privatization. ${ }^{2}$ The word "rediscovered" is apt, for while an aura of modernity has come to surround the drive to replace public function with private entrepreneurship, ${ }^{2}$ the concept of private prisons is a venerable one; the most comprehensive early proposal for privately managed incarceration is contained in Jeremy Bentham's Panopticon, published in $1791 .^{3}$

Despite the concept's long lineage, the spectre of private prisons has created a furor of late. The instinctive reaction of many commentators has been to assert that running the prisons is something that "ought" to be done by the state. ${ }^{5}$ This Note gives rigor to that visceral response by

1. There are roughly two dozen correctional institutions under private operation or ownership. N.Y. Times, Mar. 3, 1985, at E22, col. 1. Most are juvenile or alien detention facilities, and a few are small jails. National Instrtute of Justice, The Privatization of Corrections 4-7 (1985) [hereinafter PRIVATIzation of CoRRECTIONS]. There are proposals for maximum security operations. See, e.g., Wash. Post, Sept. 22, 1985, at F1, col. 4 (proposal for Tennessee prisons).

2. See, e.g., Castro, Public Service, Private Profits, Time, Feb. 10, 1986, at 64.

3. J. Bentham, Panopticon (Dublin 1791). The Panopticon centers on an architectural plan for prisons and other institutions with similar needs. Its Inspection House is a circular building, with cells occupying the circumference and an Inspector's Lodge, situated at the center, commanding a view of each cell. Each prisoner apprehends that he or she may be under observation, and, not knowing to a certainty, refrains from impermissible behavior. 1 id. at 3-5. Bentham's primary concern was monitoring prisoners; an equally important problem, with which this Note is concerned, is monitoring jailers.

4. See, e.g., Departments of Commerce, Justice, and State, the Judiciary, and Related Agencies Appropriations for 1986: Hearings on FY 1986 Appropriations Before the Subcomm. on Commerce, Justice, State, the Judiciary and Related Agencies of the House Comm. on Appropriations, 98th Cong., 1st Sess. 450 app. I \& II at 464-83 (1985) [hereinafter Hearings] (statement of David Kelley).

5. See, e.g., id. app. I at 464 ("only government" should run prisons). 
demonstrating that serious problems may arise in attempting to ensure the fidelity of entrepreneurial jailers to societal preferences. The Note proposes a set of monitoring devices designed not only to guarantee that conditions in private prisons will be no worse than those prevailing in public facilities, but to harness existing private motivations to generate improvements in prison quality.

\section{Government Failure and Market Failure}

\section{A. Operation and Monitoring of State Prisons}

One must assume that opposition to private prisons is not grounded in reverence for the current system. Public prisons are widely recognized as fiscal $^{6}$ and humanitarian ${ }^{7}$ nightmares. Moreover, they continue to disappoint after the prisoner is released; they perform woefully the task of rehabilitation. ${ }^{8}$ These fundamental failings led to the abolition of the "hands off" doctrine ${ }^{\vartheta}$ and a wave of prison reform litigation, generating decrees touching every detail of prison administration. ${ }^{10}$ This approach has fostered improvements, but the hopes of its proponents for a major restructuring of prisons have not borne fruit. ${ }^{13}$ Administrators have little incentive to close the gap between court decrees and actual prison conditions, and no incentive at all to go beyond the narrowest reading of the orders. ${ }^{12}$

6. Privatization of Corrections, supra note 1 , at 33-37.

7. For a compelling portrayal of prison life, see J. ABBOTT, IN THE BELLY OF THE BEAST 27-62 (1981) (describing intentional starvation, blackout cells, strip cells, solitary confinement, and administration of unneeded psychotropic drugs). State-run prisons may degenerate passively into noisy, vermin-infested fire hazards with no heat, light, ventilation, sanitary facilities, personal security, or programs for rehabilitation, Palmigiano v. Garrahy, 443 F. Supp. 956, 961-64 (D.R.I. 1977), or they may be affirmatively reprehensible, incorporating the teeter board, see Jackson v. Bishop, $268 \mathrm{~F}$. Supp. 804, $811 \mathrm{n.7}$ (E.D. Ark. 1967) (inmate forced to balance for hours on rocking board) and the Tucker Telephone, see O. Fiss \& D. RENDlEMan, Injunctions 538 (2d ed. 1984) (one electrode attached to penis, one to big toe, and generator from ring-type telephone cranked to create current). Despite the horror of the enumerated abuses, the greatest unwarranted burden on prisoners may be the arbitrary implementation of rules and exercise of authority by guards. See L. ORLAND, PRISONS: Houses of DARKNess 69 (1975); see also J. ABBotT, supra, at 19, 63-75.

8. See, e.g., Pugh v. Locke, 406 F. Supp. 318, 326 (M.D. Ala. 1976) (prison conditions make "dehabilitation inevitable"), affd sub nom. Newman v. Alabama, 559 F.2d 283 (5th Cir. 1977), cert. denied in pertinent part, 438 U.S. 915 (1978). Twenty-five percent of all prisoners return to prison within two years of release. NAtional. InStitute of JUSTICE, RETURNING to PRISON 2 (1984) [hereinafter ReTURNING To PRISON].

9. For an application of this doctrine, see Banning v. Looney, 213 F.2d 771 (10th Cir. 1954) (refusing to review discretionary administrative acts).

10. See, e.g., Palmigiano, 443 F. Supp. 956 (decree specifying treatment programs and standards for physical plant). Eighth Amendment violations have been found in twenty-six states. Hearings, supra note 4, app. II at 474.

11. See Note, "Mastering" Intervention in Prisons, 88 YALE L.J. 1062 (1979) (outlining inherent conflicts in special master's role in implementing decrees). Although courts have declared standards, and lawsuits probably have curtailed the worst abuses, it cannot be argued that such suits have solved the prison problem. Id. at 1073 n.61, 1081.

12. Administrators and legislators alike may resent judicial incursion onto their "turf." See id. at 1073-76. Even guards, who have a vested interest in the status quo, will resist change. See J. JAcons, 
Even if decrees were transformed flawlessly into reality, there would be great weaknesses in relying on litigation to monitor prisons. Prison reform litigation is slow ${ }^{13}$ and costly and places a great strain on judicial resources. ${ }^{14}$ Litigation is also a fairly clumsy instrument for preventing wrongs because suits generally can be brought only after a wrong of a certain magnitude has been committed. ${ }^{15}$ Finally, prisoners may decide whether to litigate on grounds other than the suit's projected success. ${ }^{16}$

The failure of state-run prisons and the problems of court-led reform do not, however, lead ineluctably to the conclusion that private prisons must signal an improvement. To the contrary, significant factors suggest that private prisons could be inferior to their public counterparts in both quality and efficiency.

\section{B. Divergence of Duty and Interest}

Proponents of prison privatization argue that private prisons will generate many efficiencies. ${ }^{17}$ The promised economies present powerful temptations to change. In general, as Bentham observed, it is always preferable to have a manager in whom duty and interest are united..$^{18}$ Private man-

StAteville 82 (1977); see also id. at 113-16 ("[c]ourt decisions do not enforce themselves," and administrators violate "clear meaning, if not the letter" of decrees). There are thus "agency costs" in decree implementation. See infra note 19.

13. See J. JACOBS, supra note 12, at 122 (describing "glacial progress" of prison cases).

14. The decree is only the beginning of a continuing relationship between judge and prison. Ruiz v. Estelle, 679 F.2d 1115, 1163 (5th Cir. 1982) ("implementation of . . . decree can become a ceaseless guerrilla war, with endless hearings, opinions, and appeals, and incalculable costs"). By requiring a judge to frame an order that can cover myriad contingencies, J. JAcoBs, supra note 12, at 113, prison reform litigation makes great demands on the court's omniscience and prescience. See, e.g., Palmigiano, 443 F. Supp. at 986-90 (order encompassing cell size, garbage collection, and prisoner/ toilet ratio); $c f$. O. Williamson, The Economic Instrtutions of Capitalism 45 (1985) (discussing problem of "bounded rationality"). The problem is accentuated if judges do not understand prison operation. See Note, supra note 11, at 1075 n.70.

15. Holt v. Sarver, 309 F. Supp. 362 (E.D. Ark. 1970), affd, 442 F.2d 304 (8th Cir. 1971), may have generated a justly celebrated prison reform, but if the Tucker Telephone is a necessary precursor to such results, the monitoring system has already failed. The need is for remedies that prevent such violations altogether.

16. Prisoners may fear retribution, see Talley v. Stephens, 247 F. Supp. 683, 690-91 (E.D. Ark. 1965), and litigate only in dire situations (i.e., after the system has failed, see supra note 15); on the other hand, some may view litigation as recreational or vindicatory and bring a costly batch of frivolous suits. Cf. Galanter, Why the "Haves" Come Out Ahead: Speculations on the Limits of Legal Change, 9 LAw \& Soc'y REv. 95, 137 (1974) ("have-nots" often litigate for symbolic rather than material gratification). Also, prisoners' preferences regarding prisons will systematically misrepresent those of society at large; suits alone cannot align prison conditions with society's ideals. A prisoners' suit will even misrepresent the views of some prisoners. See Note, supra note 11, at 1079 .

17. For-profit firms have incentives to innovate in personnel deployment and facility design. They are free of the retirement benefits and patronage obligations of the public sector. Private firms are able to construct a facility more quickly than is the state. They may also be better able to take advantage of economies of scale and spread the risk of facility shutdowns. See, e.g., NATIONAL INSTItute of Justice, Corrections and the Private Sector: A National Forum 77-78 (1985).

18. $3 \mathrm{~J}$. BeNThaM, supra note 3 , at 20-21. 
agement does not, however, necessarily unite duty and interest. ${ }^{19}$ Two characteristics of prison operation, its inaccessibility to the public and its typical arrangement in monopolistic form, will, in combination with the profit motive, ${ }^{20}$ cause the firm's interest to diverge from its duty to implement societal preferences. ${ }^{21}$ Unchecked, the very forces that allow private firms to offer pecuniary savings can drive them to sacrifice prison conditions, and even efficiency, in ways that public stewards will not.

\section{Hidden Delivery}

A particular sort of market failure occurs when the purchaser of a good is unable to observe its consumption. In such a case, the purchaser cannot accurately gauge the quantity and quality of the good delivered. The supplier may therefore provide to the consumer less than was purchased and retain the residual without fearing sanctions from the unwitting buyer. ${ }^{22}$ Some services provided by prisons take this form. ${ }^{23}$

19. A government's contract with private management creates an agency relationship. The firm is hired to serve the state, but the firm will carry out the state's will imperfectly in order to serve its own ends. Jensen \& Meckling, Theory of the Firm: Managerial Behavior, Agency Costs and Ownership Structure, 3 J. Fin. ECON. 305, 308 (1976). The sum of the costs of limiting these divergences and the residual welfare loss stemming from actual failure of the agent to maximize welfare for the principal is the "agency cost" of the relationship. Id.

20. These factors increase agency costs by raising monitoring costs and by strengthening the firm's ability and incentive to follow its own agenda. Id. at 328-29.

21. An antecedent problem facing any mechanism for monitoring divergences between actual prison operations and societal preferences is the exact determination of societal preferences. See generally K. ARRow, Social Choice and Individual Values (rev. ed. 1963) (proving theoretical impossibility of defining perfect societal preference function). This Note takes societal preferences to include constitutional guarantees as well as popular sentiment. In this broad sense, societal preferences are the dispositive guide to the form our prisons ought to take. Identification of the component parts of societal preferences does not make the divination of those preferences a simple task. The necessary tension among the various ends of imprisonment, see infra note 23 , complicates determination of the community's desires. As Bentham put it:

Some forget that a convict in prison is a sensitive being: others, that he is put there for punish-

ment. Some grudge him every gleam of comfort or alleviation of misery of which his situation

is susceptible. To others, every little privation, every little unpleasant feeling, every unaccus-

tomed circumstance, every necessary point of coercive discipline, presents matter for a charge of inhumanity.

$3 \mathrm{~J}$. BENTHAM, supra note 3 , at 3 .

22. This form of market failure is described in Hansmann, The Role of Nonprofit Enterprise, 89 YALE L.J. 835, 846-47 (1980). Hansmann suggests that a paradigmatic example of the potential for such market failure is the delivery of food aid to distant lands. The donor is unlikely to travel to the needy country or otherwise to discover what the funds have bought. Id. at 847 . Hansmann concludes that the nonprofit form protects the purchaser in cases of hidden delivery because the constraint on the distribution of profits, by making appropriation of any illicit surplus more difficult, dulls a manager's incentive to skimp. Id.

23. Society imprisons for a variety of purposes: retribution, deterrence (including incapacitation), and rehabilitation. See, e.g., N. MORRIS, The FUTURE OF IMPRISONMENT 13-14 (1974). Society also constrains the means available to achieve these ends. See, e.g., Holt v. Sarver, 309 F. Supp. 362 (E.D. Ark. 1970), affd, 442 F.2d 304 (8th Cir. 1971) (holding general prison conditions violative of Eighth and Fourteenth Amendments). Some ends of imprisonment, such as incapacitation, are readily observable by the purchasers of incarceration services, the taxpayers. Rehabilitation, humane treatment, order, and protection of constitutional rights are more difficult to observe. The hidden delivery prob- 
Any prison manager might exploit this potential for abuse to further private ends. A for-profit enterprise will, however, be systematically more likely to do so than will the state, even if one can assume that both entities care equally about serving the public welfare. ${ }^{24}$ There are constraints on the ways that a public administrator can convert abuses into private gain. ${ }^{25}$ The making of profits, on the other hand, is not punishable by law and need not be attended by conspicuous consumption of perquisites. Entrepreneurial jailers benefit directly, in the form of increased profits, from every dime not spent. There is thus a much greater incentive for the private firm to cut corners, and dimes that are difficult to trace become a matter of some concern for taxpayers.

\section{Entrenchment}

A related set of concerns arises from the likelihood that letting a private corrections contract would create, if not a state-sanctioned monopoly, a very entrenched industry. At first, the market for prison services may be competitive, but the firm securing the initial contract could acquire a wellnigh unassailable position for subsequent rounds of bidding, especially if it owns the only suitable facilities or employs most of the persons in the area with experience in corrections work. ${ }^{26}$

lem is an important part of the distinction between the state's delegation of incarceration and the state's use of private contractors in other areas, such as architecture and roadbuilding. Taxpayers can readily see whether buildings have crumbled or roads have buckled. For the other key distinction, the special character of incarceration, see infra notes 27,31 .

24. It is probable that public-spiritedness will not be distributed randomly across the two management forms. The state's enterprises are likely to include a certain number of persons drawn by the prospect of serving the public welfare. Those state prison officials, imbued with the ethic of public service, will be less likely than their private counterparts to enrich themselves by reducing services.

25. Salaries are not directly increased by such "savings." In essence, the state plays the fiduciary role of Hansmann's nonprofit organization. Hansmann, supra note 22 , at 845 . The state, like a nonprofit entity, is constrained in its distribution of profits and thus has less incentive to skimp than have its for-profit counterparts. The benefits of skimping must be enjoyed as perquisites, which are a lightning rod for public disgruntlement, and, as in-kind payments, provide less utility than their equivalent value in cash. See Posner, Natural Monopoly and Its Regulation, 21 STAN. L. Rev. 548, 602 (1969). Moreover, attempts to include the cash value in take-home pay are illegal and carry heavy sanctions. This risk reduces the value of expropriated cash. Because the probability of detection rises with the amount taken, the marginal value of each dollar embezzled declines. Nevertheless, reliance on this policing effect of nonprofits, whether they are private or organs of the state, is an imperfect solution. The absence of the profit motive has an efficiency cost, Hansmann, supra note 22, at 844 , and reduces susceptibility to societal control by means of structured incentives. Indeed, it is the very inefficiency of (public) nonprofit prisons that fuels the move toward more "efficient" for-profit prisons. Private nonprofit prisons have the additional failing in relation to state facilities of being less politically accountable.

26. See O. Williamson, supra note 14 , at 61 . Williamson describes a "fundamental transformation" that can give the winner of a competitive initial bid a great advantage over all other bidders in subsequent rounds. This transformation will occur if the winner employs appreciable amounts of specialized human or physical capital, capital peculiarly suited to the particular transaction, in providing the good or service. Monopoly power need not, however, be an inevitable consequence of the choice of a single bidder. As long as there are viable competitors at the initial bid and at subsequent rebids, monopoly power will not arise. Id. at 329. 
Accordingly, the state may have a strong interest in keeping the original firm on the job. Not only may that firm be free of the costs of entry into the market faced by every other firm, and thus be able to offer lower prices, but this persistent price advantage might mean, over time, that other firms will lose interest in trying to enter the market. Significantly, the excessive payments that the firm's entrenched position would allow it to exact need not come exclusively in the form of higher fees. The firm might also choose to increase its return by reducing its costs and allowing prison conditions and services to fall below the societally preferred level..$^{27}$ If the state cannot return to a competitive market to rebid the contract, ${ }^{\mathbf{2 B}}$ sanctions for misfeasance will be inadequate to halt these abuses, even if the abuses are detected. The state will be constrained not to penalize the firm heavily enough to drive it from business. ${ }^{29}$ Even an ideal system for monitoring deviations of actual prison conditions from societal preferences will be worthless absent a complementary system for controlling the economic power of the entrepreneurial jailer.

\section{G. The Failure of Traditional Monitoring}

The particular difficulties of hidden delivery and entrenchment ${ }^{30}$ coupled with the inadequacy of judicial oversight even of state-run facilities, imply that special steps must be taken to monitor the private prison. ${ }^{31}$ In

27. Delegation of imprisonment is problematic because it involves control over a liberty interest. At some lower levels of prison quality, additional infringements of liberty may be justifiable only by enormous cost savings, if at all. The prison firm will be indifferent between netting an additional dollar by raising its price and achieving the same result by reducing quality and hence costs. Society, on the other hand, will care and will prefer paying higher prices (or abolishing prisons) to witnessing a further decline in quality. (Another way of stating this point is that the societal indifference curves between prison quality and cost saving are discontinuous at some minimum level of prison quality. The decline in utility brought about by a reduction in quality from just above that threshold to just below it can be compensated only by a gigantic pecuniary saving, if at all.) If inordinate market power cannot be prevented, it may be important to channel it toward higher monetary prices and not lower quality.

28. Once it has contracted out incarceration, the state, like any entering firm, will face start-up costs. It may be cheaper for the state to accept some contractor abuses than to remedy them by resuming state operation. The firm's market power can drive the state from the marketplace just as it can private competitors.

29. See O. Williamson, supra note 14, at 62 (transactions involving specialized assets make each party dependent on other).

30. In battling these evils, the monitoring system must meet another concern. The delegation of incarceration involves transfer of the state's monopoly on the legitimate use of force and restriction of liberty. It is important not only that the system function well, but that it be perceived to function well, in order that public faith in the integrity of American justice be maintained. See, e.g., Richmond Newspapers, Inc. v. Virginia, 448 U.S. 555, 571-72 (1980) (plurality opinion) ("II]t is important that society's criminal process 'satisfy the appearance of justice,' and the appearance of justice can best be provided by allowing people to observe it." (citation omitted)).

31. Much of the debate over private prisons has centered on the state's constitutional authority to delegate a task so central to our system of criminal justice. See, e.g., Hearings, supra note 4, app. I at 464. Solving the monitoring problem will, however, answer many objections to the propriety and permissibility of such delegation. In some sense, the corrections function is always delegated by the 
abstract form, the problem posed is that of monitoring a function that society trusts government to carry out itself ${ }^{32}$ when government has delegated that function to an entity that society does not trust. The obvious response, and the one that now prevails in the realm of prison privatization, ${ }^{33}$ is to make government the monitor. Surely the state can be trusted to monitor an activity that it is trusted to perform.

Several factors suggest, however, that the state as monitor will be less reliable than the state as administrator.$^{34}$ First, the costs of administrative review $^{35}$ will appear in the budget of the government that let the prison contract, perhaps with much fanfare, for the express purpose of saving corrections dollars. That entity will not allow the sum of the contract price and the cost of monitoring to exceed the costs it incurred itself in running the prison system. Monitoring expenditures are thus capped by a criterion wholly unrelated to prison quality. ${ }^{36}$ The monitoring agency will have a similar reason not to monitor the firm too closely; the agency, or one closely allied with it, selected the firm and will be tarred with the same brush if improprieties are discovered. ${ }^{37}$

If no ready competitive market exists to which the state can turn for another operator, the monitoring agency may recognize that the state has

state, to some salaried employee. On this view, the state is simply a legal fiction, "a nexus for a set of contracting relationships among individuals." Jensen \& Meckling, supra note 19, at 310 (emphasis omitted). We accept without qualm the state's prerogative so to delegate, both as a practical matter and because the constraint on the distribution of profits by the state, see supra note 25 , perhaps combined with a perceived commitment to public service, see supra note 24, and a sense of greater political accountability, reassures us that the institutional arrangement is sufficient to monitor and to check the tendency of state employees to self-enrichment, and to guarantee their fidelity to societal preferences. When the organizational form changes from state hiring of private individuals to state hiring of a private firm, the problem remains the same: how to ensure that public duties are not sacrificed to private interest. Different monitoring mechanisms may be employed, but if they are as successful as those deemed acceptable under state management, the objection that the state has no authority to delegate cannot seriously be raised.

32. The trust may not be wholehearted, but it is sufficient to allow prison operation.

33. N.Y. Times, Feb. 11, 1985, at B6, col. 3 (facilities inspected and monitored by state).

34. It remains to be demonstrated that another monitor can perform more ably. Cf. Coase, The Regulated Industries-Discussion, 54 AM. EcoN. Rev. (Papers and Proceedings) 194, 195 (1964) (relevant comparison is "between social arrangements which are all more or less failures").

35. Such costs are not inconsiderable. In the wake of Ruiz v. Estelle, 679 F.2d 1115 (5th Gir. 1982) (finding Texas state prison conditions to violate Eighth Amendment), "a special master with a staff of attorneys and investigators and an annual budget in excess of half a million dollars is required to monitor compliance with a judicial decree seeking merely to eradicate cruel and unusual punishment." Hearings, supra note 4, app. II at 481-82. One could expect effective general monitoring to cost more.

36. Often, the governmental entities that contract out incarceration do so because they face tight budgets and hence have few discretionary funds. See Wash. Post, Sept. 22, 1985, at F9, col. 1. Even if the sum of immediate cost saving from privatization and the expected value of future cost-saving innovations were greater than the added costs of monitoring, such an entity might not monitor adequately if the immediate cash flow were negative.

37. For an early example of suppression by official inspectors of grievous wrongs occurring within a penitentiary, apparently because the inspectors viewed themselves as advocates of the particular penal system, see H. Barnes, The Evolution of Penology in Pennsylvania 161-62, 306-07 (1927). 
no interest in acting on the agency's findings, and the agency may therefore decline to publish, or even investigate, abuses. Furthermore, administrative monitoring is subject to the phenomenon of "capture" of the regulator by the regulated entity. ${ }^{38}$ Finally, state monitors face formidable difficulties in determining societal preferences with respect to prison operation ${ }^{39}$ and in implementing those preferences. ${ }^{40}$ Governmental monitors have little incentive to push prison conditions beyond a legislated or courtimposed minimum standard.1 ${ }^{41}$ Their job is complete when that standard is met.

\section{A Propósed Solution}

Trepidation over private prisons is, in light of the foregoing, justified by the divergence of the firm's interest from its duty and by society's seeming inability to narrow that gap. This Note proposes a monitoring system designed to channel private interest to coincide with public duty. ${ }^{42}$ By harnessing private motivations, the system not only ensures that private prisons will be as faithful to societal preferences as are state-run prisons, ${ }^{43}$ but it also creates a means of actually improving prison performance.

\section{A. Monitoring of Prison Conditions}

\section{Fines and Bonuses}

The profit motive, which makes private prisons problematic in the first place, means that their owners will feel, and hence respond to, pecuniary incentives much more acutely than will public administrators. If an

38. A captured regulator favors the regulated industry, either because the industry is more organized than the public at large, see Stigler, The Theory of Economic Regulation, 2 BELL J. ECON. \& MGMT. ScI. 3, 10-13 (1971), or because the agency is populated by employees, past, present, and hopeful, of the regulated industry. See G. Adams, The Iron Triangle 77-83 (1981) ("revolving door" between Pentagon and defense contractors creates subtle conflict of interest for government official contemplating future private employment). Capture might seem to be at odds with the suggestion that government employees may be systematically more public-spirited than their private sector fellows. See supra note 24 . Nevertheless, the chance for pecuniary advantage may draw to the public service those who might have spurned it otherwise. Also, privatization will over time imply that those deemed to have the requisite expertise for monitoring will necessarily be former employees of the industry.

39. Administrative monitors are accountable only indirectly to the voters; there is no systematic mechanism for aggregating societal preferences regarding prison operation. The monitors also need make no systematic reports of findings to aid in the formation of public preferences. Cf. A. Meiklejohn, Polrtical Freedom 14-28 (1965) (citizen, as sovereign, needs information to govern responsibly).

40. See supra notes 11-12.

41. See G. Stigler, Regulation: The Confusion of Means and Ends, in The Citizen and THE STATE 171 (1975).

42. See Kraakman, Gatekeepers: The Anatomy of a Third-Party Enforcement Strategy, 2 J.L. ECON. \& ORG. 53, 94 (1986) (monitoring efficiency improved by tapping existing motivations).

43. Equivalent quality is the minimum, if unsatisfying, standard for permitting private prison operation, given the economies involved and the continuing need for some sort of prison. 


\section{The Panopticon Revisited}

agency is fined for a violation, services will simply fall in direct proportion to the budget reduction. ${ }^{44}$ In contrast, a fine imposed on a competitive firm will directly affect profits. The firm will not have the option of reducing services proportionately because a cutback in services to preserve profit margins does not have the legitimacy in the public eye of a reduction mandated by an inadequate budget. Moreover, a fine system could punish those very cutbacks, making such a strategy counterproductive.

Properly set fines ${ }^{45}$ will operate to align private interest with public duty $^{48}$ and will create market incentives to innovate in care and rehabilitation. ${ }^{47}$ Fines and the implicit bonuses accompanying them ${ }^{48}$ can be used to

44. The argument that services must be reduced because the public fisc is inadequate is one society is inured to accepting. See, e.g., Note, supra note 11, at 1067 n.31. Fining public officials personally might be more effective, but fines for other than extraordinary occurrences would impart such a degree of risk to public office as to make the positions wholly unattractive, absent some countervailing prospect of above normal returns. See Kraakman, Corporate Liability Strategies and the Costs of Legal Controls, 93 Yale L.J. 857, 887 (1984). The state might be forced to staff prisons with judgment-proof personnel or to install a system of profit distribution to implement such fines. By following the latter course, though, the state would essentially have privatized the prisons within the public framework. Otherwise, bureaucrats would deal with the personal risk by passivity or by seeking some "safe harbor" standard of conduct. P. Schuck, SuIng GovernMENT 68-77 (1983).

45. To ensure that the fines reflect societal valuations of the harms and benefits in question, the fines should be legislatively set. The legislature is particularly suited to set fines because the exercise is one of valuing societal preferences, not specifying technical standards. The fine setting process does not involve planning menus and designing cells, activities for which a regulator's expertise is needed, but rather making the judgment that too many deaths by disease are occurring and that society will pay more to reduce their frequency. Such tasks are quintessentially legislative.

One of the most attractive features of the fine system is its potential for bridging the implementation gap regarding a second source of societal preferences, judicial decrees. See supra notes 11-12. The legislature should confer with the special master in establishing fines. The fines can be used either to implement court-ordered standards or to signal to the firm society's marginal valuation of improvements. At the beginning, iterative adjustments might be needed to find the correct level. See Baumol \& Oates, The Use of Standards and Prices For Protection of the Environment, in The Economics of ENVIRONMENT 53-54 (P. Bohm \& A. Kneese eds. 1971). Fines could be graduated to follow varying marginal preferences.

46. The internalization to the firm of societal preferences regarding prison quality will also affect the entrenchment problem. Because the firm will face the same fine/quality tradeoff regardless of its market power, it will exercise any market power by charging higher fees and maintaining the desired quality, a result arguably preferable, at some quality levels, to its alternative. See supra note 27.

47. Unlike a decree or a contract, written by a few and specifying every nuance of operation, see Hearings, supra note 4, app. II at 481 (prison contracting impossibly complex), the fine delineates a goal (reduce recidivism, e.g.) and invites every participant to achieve the goal in the most efficient way. See A. KNeese \& B. Bower, Managing WATER QualtTy: Economics, Technology, InSTrTUTIONS 133 (1968) (fines take advantage of decentralized decisionmaking). The firm's incentive is not merely to meet an administrative or judicial minimum standard; there is continuous pressure to improve conditions. See id. at 138-39. Also, the fine system is capable, by slight adjustments, of accounting for sentiments that conditions are not "all that they might be," even if conditions might not sink to the level of unlawfulness at which a court could address them. The weaknesses of litigation, supra notes 11-12, are thus mitigated.

48. The firm will bargain for a premium to cover unavoidable (at society's evaluation of cost) or expected fine triggering incidents. A certain number of deaths, illnesses, and instances of recidivism will occur regardless of the exertions of the jailer. (If not, the firm might be put in charge of society at large.) The fine system thus pays an implicit bonus for better than expected performance.

An example may clarify this point. If a firm houses three inmates, two of whom it expects to return to prison in two years, and faces a fine of $\$ 100$ for each instance of recidivism, it will increase its bid by the present value of $\$ 200$ in two years over the figure it calculates will cover operating costs and 
force the firm to consider the societal costs of its actions, ${ }^{49}$ in effect enlisting the firm as the chief monitor of its own activities. The private jailer should be required to insure the health of the inmates and to pay a fine to the state for every death in custody (or release in contemplation of death), occurrence of certain injuries and illnesses, ${ }^{50}$ escape, or instance of recidivism $^{\text {s1 }}$ involving an inmate held by the firm. ${ }^{52}$

Under such a regime, the firm will want to maintain healthful, sanitary conditions, ${ }^{\text {ss }}$ curb inmate violence, check overcrowding and forced intimacy that can contribute to the spread of disease, maintain security, and employ the best available means (or develop new techniques) of rehabilitating criminals and preventing recidivism. ${ }^{54}$ Of particular importance is

provide a normal profit. If both inmates return to prison at the expected time, the firm will repay the premium charged plus interest, or \$200. Performance at the expected level creates a wash transaction, with no penalty to the firm. If only one inmate returns to prison, the firm keeps one half of the premium charged, a reward for better-than-market performance. Similarly, the firm is rewarded by the amount of the interest earned if the prisoners recidivate later than expected. If all three prisoners return, the firm faces a net penalty.

49. See A. KNEESE \& B. BowER, supra note 47, at 78, 98 (tax on externalities forces balancing of those costs with costs of prevention).

50. Such as bullet wounds, see J. Аввотт, supra note 7 , at 66 , or hepatitis, see Holt v. Sarver, 300 F. Supp. 825,832 (E.D. Ark. 1969).

51. An important advantage of this fine system is its ease of administration. In contrast, one major difficulty of water quality fines is the task of measuring effluents and tracing them to their sources. See, e.g., A. KNEese \& B. Bower, supra note 47, at 113. Death, escape, and recidivism present easily detectable benchmarks and are good proxies for the common forms of inmate mistreatment. The firm may hide untreated illnesses more easily, but such inattention could increase the risk of death, revolt, or eventual recidivism. See infra text accompanying note 68.

52. Bentham assumed in general that jailers would have an interest in each prisoner's health because it would affect the productivity of the prison industry. $1 \mathrm{~J}$. BENTHAM, supra note 3, at $50-59,73$. He observed further that even the "useless" could be protected by fines:

I would make [the contractor] pay so much for every one that died, without troubling myseif whether any care of his could have kept the man alive. To be sure he would make me pay for this in the contract; but as I should receive it from him afterwards, what it cost me in the long run would be no great matter. . . .

.. [Under this system,] you need not doubt of his fondness of these his adopted children; of whom whosoever may chance while under his wing to depart this vale of tears, will be sure to leave one sincere mourner at least ....

Id. at 71-73.

53. For instance, a firm will not arbitrarily deny medical care if a resulting death would be costly to it. Public prison administrators have no similar impetus to provide adequate care. See Wall St. J., May 15, 1986, at 1, col. 1 (detailing instances of inmate deaths following denial of medical care).

54. The recidivism standard is the most far-reaching, both in terms of the range of in-prison behavior affected and the extent of the firm's interest in the prisoner after release. It will be in the firm's interest to ensure that prison is not a trade school in crime, and to abolish the infinite varieties of arbitrary and degrading treatment that make prisoners less fit for life outside. Consider the order in Palmigiano v. Garrahy, 443 F. Supp. 956, 986-90 (D.R.I. 1977). From overcrowding to drug rehabilitation, sanitation, and education, the goals of the decree are within the scope of the fine system, as are other abuses not mentioned in the order.

The firm will also care about the inmate after release, particularly to the extent that effective rehabilitation cannot take place in the prison setting. See generally McSparron, Community Correction and Diversion, 26 CRIME \& Deling. 226, 231-34 (1980). The firm might establish new programs (even paying prisoners to stay "clean," a path not open to the state) or subcontract to successful existing operations. (The scheme does not assume that recidivism can be reduced; it only creates an incentive to find cost-effective improvements if they exist.) If useful treatment cannot take place within 
the incentive given the firm to monitor its own guards and front line employees carefully. ${ }^{55}$ The fines will also counter the perverse incentive for the firm to create demand for its own product, ${ }^{\text {be }}$ as it could by fomenting violence among current inmates in order to scuttle parole chances, arbitrarily reducing good time, or "dehabilitating" prisoners so that they are more prone to recidivism. Such actions will, either directly or indirectly, increase the firm's fine costs.

A crucial feature of the fine system is the advantage that it confers on firms that can improve the prisons. Firms that are able to project lesser amounts of fine triggering problems will be at an advantage in every competitive bid for prison contracts. ${ }^{57}$ The legislature will be able to exert control over the amount of each sort of problem by varying the size of the fine. This direct link between legislative will and prison conditions will allow a much greater correspondence of prison conditions to societal preferences. Ironically, privatization, decried as an invitation to abuse and exploitation, carries within it the seeds of improvement in our correctional system.

\section{Public Access}

The fine system is an incomplete monitoring tool. It can fail in two fundamental ways, apart from willful breach. ${ }^{58}$ Fines cannot fully reflect societal preferences if society is concerned with conditions that are difficult to quantify. ${ }^{59}$ Further, the fine structure may malfunction if too little information about prisons is available to allow formation of the coherent societal preferences that become, through the political process, the basis of

the facility, there is no reason for requiring a long sojourn for a given inmate before making the firm responsible for recidivism. Indeed, to the extent that incarceration proves counterproductive, the firm might lobby for shorter sentences in order to facilitate rehabilitation. In general, the fines could make of the firm an important lobbyist for changes it could not make unilaterally, effecting a sort of "reverse capture."

55. See supra note 7. The obvious explanation for guards run amok is that prison authorities have had no incentive to check them. The fine system supplies a reason to reduce these internal agency costs and to bridge the gap between the custody and treatment functions. See J. JacoBs, supra note 12 , at 178 (guard's role should "be transformed from turnkey and disciplinarian to counselor and agent of rehabilitation").

56. See Privatization of Correctrons, supra note 1 , at 73. The incentive does not stop at filling existing beds. Once the existing facility's capacity is reached, a new facility will be required, and the firm's chances of winning that additional contract should be good. See N.Y. Times, May 21, 1985, at A14, col. 1 (proposal for new jail to meet overcrowding).

57. The firm bears the risk of failure, however. The fine system ensures that government pays only for success.

58. Even easily detectable fine triggering incidents, see supra note 51, can be hidden if the prison is sufficiently isolated, but such cheating would require state collusion or indifference.

59. It may be possible to bludgeon or brainwash prisoners into goodness without leaving physical scars or otherwise triggering fines. Indeed, such techniques could be rewarded if lower recidivism rates followed. Society must look beyond the fine system to express its disapproval of such an approach. 
the fine system. ${ }^{60} \mathrm{~A}$ scheme of public access to private prisons is a useful complement to the fine structure, both filling its operational lacunae and aiding in setting and implementing fines. ${ }^{61}$

The uproar over for-profit prisons has focused the attention of the mass media on such facilities. This scrutiny, born of a mix of antagonism and curiosity regarding private contractors, ${ }^{62}$ can be expected to continue into the immediate future. Because prison firms are buying into ${ }^{63}$ a new industry, they value favorable publicity and will cooperate with the press. After the buy-in period, however, there is no reason to expect that private prisons will be any more open to the public than their public counterparts are today. ${ }^{64}$ Indeed, the facilities might be less open because private property is involved. ${ }^{65}$ An effective monitoring system must guarantee continuing long term access to relevant information. ${ }^{68} \mathrm{~A}$ cornerstone of this system is

60. See A. MEIKLEjoHN, supra note 39 (guaranteed free speech necessary for self-government). This Note argues for press access as a matter of public policy, to be granted by the legislature, and not as a First Amendment right, but the advantages for governance are the same. Mandated access to private prisons will facilitate the process of societal preference formation and revelation on which the fine system depends. Press access will also ameliorate the public perception problem. See supra note 30. Taxpayers will be able to view and evaluate the workings of the monitoring system.

61. The advantages of press and public access to governmental undertakings as a means of monitoring and checking government's power have been treated at some length, both in general and with respect to prison operation. See, e.g., Blasi, The Checking Value in First Amendment Theory, 1977 AM. B. Found. Res. J. 521; Leverson, Constitutional Limits on the Power to Restrict Access to Prisons: An Historical Re-Examination, 18 Harv. C.R.-C.L. L. Rev. 409 (1983); Lewis, A Public Right To Know About Public Institutions: The First Amendment as Sword, 1980 SuP. Cr. REv. 1; see also Richmond Newspapers, Inc. v. Virginia, 448 U.S. 555 (1980). This Note defers to those broader treatments and focuses on the particular value of public access within the proposed monitoring scheme.

62. Bentham was sanguine about the behavior of his private jailer precisely because of this antagonism and curiosity. He pointed out that the public at large does not trust an entrepreneur, and that the jailer's every move would be carefully scrutinized. $3 \mathrm{~J}$. BENTHAM, supra note 3 , at 40 . This careful examination would be facilitated by the absolute openness of the prison's physical plant. Complete access to the jailer's books and methods of management would complement the scheme. Id. at 45-48. For a survey of the history of prison access, accenting the monitoring advantages of openness, see Leverson, supra note 61 , at 412-28.

63. During "buy-in," a firm will make concessions in order to secure a contract. After becoming established and obtaining a degree of power, the firm will withdraw the concessions. See, e.g., Note, Regulating Fraud in Military Procurement: A Legal Process Model, 95 YALE L.J. 390,394 n.14 (1985).

64. The Constitution does not guarantee access. "[N]ewsmen have no constitutional right of access to prisons or their inmates beyond that afforded the general public." Pell v. Procunier, 417 U.S. 817, 834 (1974). No case has found any such right in the general public.

65. If, as seems appropriate, the right of public access is determined by the balance between state security interests and the public right to information, see Pell v. Procunier, 417 U.S. 817, 820-21 (1974) (plaintiffs argue that two distinct interests, prisoners' right to free speech and public right to information, outweigh state security interest), it is unclear what effect privatization has on the argument for access. Although the addition of a private property interest weighs against access, the hidden delivery problem increases the public interest in obtaining access. Cf. PruneYard Shopping Center v. Robins, 447 U.S. 74 (1980) (access to private property, guaranteed by state right to free speech, does not infringe property right if not unreasonable impairment).

66. If the firm itself controlled access, bias would clearly result. Similarly, state determination of access would reflect governmental biases and be subject to capture. The choice is not between full access and a total informational blackout, but between access and the one-sided flow of information 
the power to obtain private interviews with inmates specifically selected by members of the press. ${ }^{67}$ Abuses not fully deterred by the fine system, such as denial of some forms of medical treatment or excessive leniency, or abuses actually encouraged by the fine system, such as an unwarranted propensity to sponsor sickly or violent inmates for parole ${ }^{68}$ could be readily discovered in the course of such interviews. Tours and interviews should be available on the shortest possible notice, ${ }^{69}$ and no part of the facility should be permanently off-limits. This requirement of instantaneousness and completeness will magnify the monitoring impact of public access. ${ }^{70}$

Access should not be limited to the physical plant of the prison. Records relating to disciplinary proceedings, levels of inmate violence and illness, post-release job placement, life expectancy, and recidivism should be maintained and made available by the firm. In conjunction with face to face interviews, physical access, and other public records, these records will provide a means of detecting fine cheating by the firm. ${ }^{71}$ Such records also will be invaluable in the setting of fines and in the evaluation of the efficacy of those fines. ${ }^{22}$

There are legitimate penological rationales for limiting the terms and scope of public access to prisons: prison security, public safety, program effectiveness, and prisoner privacy. ${ }^{73}$ These objectives can be served by

that any rational (or opportunistic, see O. WiLliamson, supra note 14, at 64-67) firm would elect to generate. One should also observe that the press has an impressive internal monitoring mechanism for combating inaccuracies. For journalists and academics, bias or error on the part of one of their colleagues is always news, especially if the colleague is of a different political stripe.

67. See Saxbe v. Washington Post Co., 417 U.S. 843, 853-56 (1974) (Powell, J., dissenting) (noting with approval, in companion case to Pell $v$. Procunier, finding of district court that private personal interviews with inmates selected by journalists are essential to accurate and effective prison reporting).

68. A heavy fine for violent recidivism would further counter the incentive to reduce disturbances by sponsoring violent inmates.

69. There is reason to be skeptical of guided tours given with appreciable notice: See, e.g., Holt v. Sarver, 309 F. Supp. 362, 367 (E.D. Ark. 1970) (describing favorable impression created by "staged" tours), affd, 442 F.2d 304 (8th Cir. 1971).

70. Bentham's principle for watching prisoners, see supra note 3 , translates easily into a rule for watching the watchers of prisoners: if they suspect that they are being watched or soon will be, the actual watching need not be quite so assiduous.

71. Even rudimentary recordkeeping can curb the worst abuses, such as the clandestine burial of slain prisoners in secret gravesites. See O. FISS \& D. RENDLEMAN, supra note 7, at 530-31.

72. Keeping such records will be neither expensive nor onerous, especially since the firm may voluntarily collect these data to aid in reducing the fines it must pay.

73. The Supreme Court has identified deterrence, rehabilitation, and internal security (encompassing, presumably, safety of both inmates and free citizens) as "legitimate penal objectives" against which other rights and interests must be weighed. Pell v. Procunier, 417 U.S. 817, 822-23 (1974). The Court held recently, in Hudson v. Palmer, 468 U.S. 517, 522-30 (1984), that prisoners can have no legitimate expectation of privacy if those privacy rights interfere with correctional needs and objectives. Privacy is nonetheless a value worth promoting, both in its own right and, perhaps, as an aspect of rehabilitation. Time, place, and manner restrictions on access based either on privacy concerns or on traditioial correctional objectives, should, however, be crafted as narrowly as possible, both for the instrumental reason that greater access means more monitoring power and because prisons, as "public 
limiting public access to the press. ${ }^{74}$ The term "press" should nevertheless be given a broad construction to encompass groups whose interest in the topic will not wane, such as academic researchers, members of "prison projects, ${ }^{, 75}$ and reporters for specialized newsletters. ${ }^{78}$

Public goals and the motives of the private press can be made to coincide even more closely by the crafting of "newsworthy events" to kindle popular interest. By attracting the mass media, such events will have particular utility in stimulating public debate on prisons and imprisonment. Periodic rebidding of the prison contract ${ }^{77}$ or surprise official inspections ${ }^{78}$ of prison facilities or records would serve this function.

The use of press access as a monitoring device has the great advantage of harnessing private motivations of the press, ${ }^{78}$ as channeled by the structure of the monitoring program, in the service of the public interest. Public monitoring expenditures and agency costs are thus minimized, and society obtains the collateral benefit of greater public awareness of prison problems.

\section{Monitoring by Prisoners}

Prison inmates constitute the third leg of the monitoring triad. Prisoners are a vital source of raw information on the day to day functioning of the facility, and as such are crucial to the success of the public access branch of this monitoring system. ${ }^{80}$ The monitoring structure must pro-

institutions . . . [and] an integral component of the criminal justice system," Houchins v. KQED, Inc., 438 U.S. 1, 36 (1978) (Stevens, J., dissenting), are of vital public concern.

74. Prison visits by every concerned (or curious) citizen could create burdensome levels of traffic. Our society has come to rely on the press for examination of many inaccessible or faraway phenomena that are nevertheless crucial to our political decisionmaking. Reliance on the press in this instance does not seem misplaced.

The average citizen is most unlikely to inform himself about the operation of the prison system

by requesting an interview with a particular inmate with whom he has no prior relationship.

He is likely instead, in a society which values a free press, to rely upon the media for information.

Pell v. Procunier, 417 U.S. 817, 841 (1974) (Douglas, J., dissenting). Journalists play a crucial role in checking governmental abuses, a task grown too complex and time consuming for the average citizen. See Blasi, supra note 61 , at 541-42.

75. See J. JACOBS, supra note 12, at 120-23 (legal services groups as liaison with legislators and as goad to prison officials).

76. One concern over reliance on public access for monitoring is that the public mind may wander. Inclusion of specialized enterprises under the press rubric will ensure vigilant monitoring. The reports of such organs are considered by legislators, judges, and public and private administrators, and thus have an impact on the public debate at an important level.

77. See infra text accompanying notes 85-88.

78. The reliance is not on administrative monitoring prowess but on the inherent newsworthiness of an official inquiry.

79. These motivations might include both the wish for pecuniary profit and a more direct desire to work in the public interest.

80. Protections against cruel and unusual punishment "may derive more practical support from access to information about prisons by the public than by occasional litigation in a busy court." Houchins v. KQED, Inc., 438 U.S. 1, 37 (1978) (Stevens, J., dissenting) (footnote omitted). 
vide reasonable guarantees that the prisoners will confide in representatives of the press. ${ }^{81}$

Despite the weaknesses of prison reform litigation, ${ }^{82}$ such suits are a necessary adjunct to the monitoring system. First, the fine-plus-access monitoring scheme as hereinbefore treated is effective primarily against legitimate, solvent firms. Injunctions and extraordinary fines or criminal penalties may be the only means of checking the pathological case. ${ }^{83} \mathrm{Sec}-$ ond, absent interplay with the courts, the fine structure is ultimately majoritarian. Increased public participation in the determination of prison conditions is good, but the legislature will not always successfully harmonize immediate societal demands with constitutional strictures. Litigation may provide the only sure method of incorporating the elements of societal preference expressed in constitutions but not on ballots. ${ }^{84}$ Finally, the fine system provides no compensation for inmates injured by reckless conduct; suits for such recovery should be available.

\section{B. Preventing Entrenchment}

This scheme for monitoring firm misbehavior within the prison walls must be complemented by a contracting structure that will neutralize any inordinate advantage the firm might acquire on winning the initial bid. ${ }^{85}$

81. The advantages of face to face interviews, see supra note 67 , will be nil if prisoners cannot or will not participate. Prisoner suspicion may have to be allayed before prisoners will speak openly. See J. JACOBS, supra note 12, at 218-21. Inmates will speak with the press if their interests dictate. See Leverson, supra note 61, at 447 (rioting prisoners typically demand press access). This kind of informational bias can be overcome by general availability of objective prison data and face to face interviews. See Saxbe v. Washington Post Co., 417 U.S. 843, 853-856 (1974) (Powell, J., dissenting) (face to face interviews allowing follow-up questions, observation of demeanor, and privacy operate to combat distortion).

Another concern is silence caused by fear of retribution. Because most forms of retribution will be checked by the fine system, and because fine triggering incidents are designed to be readily detectable regardless of inmate cooperation, supra note 51 , a firm will usually find silencing prisoners through intimidation to be an inefficient practice. The self-executing nature of the fine system does not, of course, make the interviews surplusage. Prisoner interviews will be most useful in informing societal preferences and revealing activities not reached by fines.

82. See supra notes $9-16$ and accompanying text. The enumerated weaknesses explain why prisoners cannot be the primary monitors.

83. It is appropriate that the system focus on preventing abuses in the normal course of business, but attention must be given the fly-by-night firm and the end-game player, see Scholz, Cooperation, Deterrence, and the Ecology of Regulatory Enforcement, 18 LAw \& Soc'y REv. 179, 218 (1984) (firm near bankruptcy ignores future outcomes), who are undeterred by bad publicity, fear of losing the next contract, or the prospect of future fines.

84. Such suits may be particularly useful in defining and maintaining the minimum acceptable standard. See supra note 27 . In general, suits to vindicate individual rights preserve a balance between those rights and the quest for "the greatest good for the greatest number" embodied in majoritarian preferences. Cf. Armstrong, The Retributivist Hits Back, in The Philosophy of Punishment 138, 152 (H. Acton ed. 1969) (criticizing utilitarian justification for punishment).

85. See supra note 26 . Despite the fine system, see supra note 46 , the firm will be able to translate its market advantage into lower prison quality if the legislature is convinced that the public interest in keeping the firm on the job (a "public interest" created by the firm's market power and the resultant high cost of replacement) will be served by setting fines lower than society's true evaluation 
Fines and public outcry against the private jailer will avail little if barriers to subsequent entry make a shift to another provider impracticable, even if the new firm's fine costs would be significantly lower than those of the firm under contract. To avoid sacrificing prison quality to fortuitously acquired market power, the state must exert itself to promote competition.

\section{Optimal Contract Duration}

The argument for privatization relies heavily on the salutary effects of competition. The spur of competition is, however, effective only if regularly applied. For this reason, prison contracts should be rebid at some interval. ${ }^{86}$ Frequent rebidding will force the incumbent firm to implement its innovations in order to keep its costs low and will quickly reward innovators who can project lower fine costs by allowing them to win contracts soon after their breakthroughs. In fact, the frequency of rebidding will determine whether other firms pursue innovation at all. ${ }^{\mathbf{8 7}}$ Finally, shorter contracting periods reduce demands on the parties to foresee all eventualities. ${ }^{88}$

On the other hand, extremely short term contracts increase the risk that a particular innovation or investment will not pay for itself in lower fine costs before the firm is ousted, thereby reducing the incentive to innovate or undertake specialized investment. ${ }^{88} \mathrm{~A}$ short time horizon can also

of the harmfulness of transgressions. The same result could obtain if the state administrators of the fine system initiated a kickback scheme, effectively lowering the fine rate in a manner less detectable than legislative action or the falsification of recidivism records. If the sole danger were that the firm might earn an above-market rate of return, a simple solution would appear. In a competitive bid, the state would receive at the outset the equivalent of the payments later to be extracted from it, with no apparent net loss to society. See Demsetz, Why Regulate Utilities?, 11 J.L. \& EcoN. 55, 65 (1968). Indeed, the firm would receive no monopoly profits, but it would still charge the inefficient monopoly price, either by raising its price per prisoner or by reducing quality as suggested above. Allocative efficiency would suffer as the state reacted to higher imprisonment costs, and especially as fewer resources are devoted to prison quality than society desires. See Telser, On the Regulation of Industry: A Note, 77 J. Pol. Econ. 937, 938-39 (1969).

86. Compare Bentham's proposed grant of life tenure, absent flagrant misbehavior. $1 \mathrm{~J}$. BENTHAM, supra note 3 , at 42 .

87. Long term contracts can effect a different sort of fundamental transformation, see supra note 26 , by destroying the incentive for losing bidders to remain poised to enter the prison business. The state has an interest in maintaining a "mobilization capability," $c f$. J. GaNSLER, THE DefENSE INDUSTRY 56, 72-82 (1980) (interest in readiness of defense contractors for emergencies thwarted by lack of competition in defense industry), of successor firms capable of relatively quick entry in order to avoid extortion by impending bankruptcy and to maintain a credible threat of dismissal for breach. The state may not be able to fill this gap itself; governmental seizure and operation of a going business can be fraught with pitfalls, including valuation problems, management difficulties, and the need for statutory authorization. Cf. Youngstown Sheet \& Tube Co. v. Sawyer, 343 U.S. 579, 585 (1952) (executive order to seize steel mills in wartime invalid absent congressional authorization). Short term contracts would operate to ensure such a mobilization capability. State ownership of important specific capital assets, see infra text accompanying note 99 , can further guarantee mobilization capacity by reducing transition costs.

88. See O. WIn.liamson, supra note 14 , at 339 (short term contracts allow adaptation).

89. Except for investments in capital, see infra text accompanying note 95 , the primary invest- 
render nugatory fines for abuses that will manifest themselves only after a lapse of time. ${ }^{90}$ The optimal contract span is determined by the tradeoff among these factors, the nuances of which are a matter for empirical observation. As a starting point for operations, contracts with maturities of between two and four years should be appropriate, ${ }^{91}$ depending upon asset ownership.

\section{Private Versus Public Ownership}

The primary source of entrenchment is the ownership of a specialized asset such as a prison facility. ${ }^{92}$ There are advantages in having the firm own its own capital ${ }^{93}$ and in the deployment of specialized assets. ${ }^{94}$ The firm, however, will undertake the desired investments in specific capital and innovation only if it receives guarantees, such as a contract period long enough to allow it to recoup its investment, to compensate it for the risk that it will be unable to redeploy the specialized assets on termination of the contract. ${ }^{95}$ Otherwise, the firm will use facilities that have highly valued alternative uses; disposition of such properties forced by declining demand or loss of the prison contract will not mean total loss. ${ }^{96}$ Potentially valuable investment by the firm in specialized assets will be foregone unless the firm has a fairly secure long term contract $^{97}$ or market condi-

ments that might have long maturities are those in personnel and rehabilitation. Because training is usually of short duration or done on the job, infra note 92 , and because measures against recidivism must operate quickly, infra note 91 , this chilling is unlikely to be significant in these areas.

90. This problem is most severe with respect to end-game plays by the near-bankrupt or fly-bynight firms that expect neither to remain in service long enough to benefit from innovation nor to exist long enough to have to pay fines. A legitimate firm will hope for a long tenure and therefore will undertake innovation and avoid abuse in the reasonable expectation of continuing on the job. The press, court cases, contractual provisions for breach, and the other fines proposed here provide protection against blatant opportunism.

91. Twenty-five percent of state prisoners return to prison within two years of release; almost one third return within three years. RETURNING To PRISON, supra note 8 , at 2 . The firm's policies will have a fair trial in that period.

92. In preparing subsequent bids, entering firms will be saddled with the enormous additional cost either of building their own units or of gambling on their ability to purchase the existing facility from a disgruntled competitor. See O. Williamson, supra note 14, at 53-54. Human capital is less likely to be a source of entrenchment. Training periods of two to six weeks are now typical for guards, see N.Y. Times, Feb. 19, 1985, at A15, col. 3, and such labor might be subcontracted to facilitate flexibility.

93. The firm will appropriate the benefits of innovation and maintenance and will modify capacity in step with changes in demand.

94. Equipment designed or persons trained specifically for one task should perform that task more efficiently. See O. Wil.Lumson, supra note 14 , at. 62 .

95. See id. at 54. The use of specialized assets makes the parties dependent upon one another, and they will arrange their affairs accordingly. Id. at 63.

96. Currently operated facilities include a converted convalescent home and a former motel. Privatization of Corrections, supra note 1 , at 67.

97. The firm might also cope with risk by diversification, entering contracts with several different governmental entities. Regional facilities would seem to present the public policy problem at a higher level of concentration, however. More havoc would be wrought by the firm's withdrawal, and its command over the broader market would make it even less likely that a competitor operating nearby 
tions after award of the initial bid are such that the state cannot credibly threaten to replace the firm, even if the nominal contract period is short.

Because there is a public interest in limiting both nominal contract length and the firm's power in subsequent rounds of bidding, ${ }^{98}$ highly specialized prison assets should be owned by the state. ${ }^{99}$ Such a prescription might seem to negate two of the chief advantages of privatization, the private firm's ability to construct new facilities quickly and its incentive to innovate in design. ${ }^{100}$ In fact, the state can realize these same benefits by means of a design competition that emphasizes economical function ${ }^{101}$ and by the use of lease/purchase agreements for construction. ${ }^{\mathbf{1 0 2}}$

could step into the breach. On the other hand, such regional facilities would increase the size of the relevant market, thereby possibly reducing the number of firms necessary to maintain adequate competition.

98. Governor Richard Lamm of Colorado expressed starkly the power that ownership confers on a firm. Referring to a contractor building a prison in Colorado without state commitment, Governor Lamm remarked: "[H]e thinks that we'll have to contract with him, and he's probably right." N.Y. Times, Mar. 2, 1986, at 35, col. 1.

99. It might appear that the state's interest in flexibility in contracting and the firm's desire for security could be reconciled either by reserving to the state an assignable option for the purchase of the facility at a fixed or arbitrated price or by the state's use of eminent domain to condemn the facility and transfer it to the winner of the new contract. $C f$. Hawaii Housing Auth. v. Midkiff, 467 U.S. 229, 243-44 (1984) (transfer of property among private persons does not violate public use requirement). Substantial litigation might ensue from condemnation of this sort, raising the cost of switching firms. The costs and uncertainties of eminent domain and its chilling of investment could lead the parties to prefer an explicit option to purchase (such is actual practice, see sample contract of Corrections Corporation of America (photo. reprint on file with author)). If the compensation standard is depreciated plant cost, (the firm is unlikely voluntarily to agree to less, and the absence of a ready market makes any other type of appraisal problematic), the state becomes the guarantor of failed investment programs by the firm, without having any say in the investment undertaken. Valuation and transition costs also will add quite a bit of friction to the system. The firm may find it very easy to manipulate accounting of original cost, $O$. Williamson, supra note 14 , at $341-43$, thereby skewing compensation upward. If the prearranged price is high, competing firms will not meet it, leaving the state either to take the loss or to leave the offending firm in place. The prospect of an inflated buyout will also make the firm marginally less assiduous in striving not to be displaced. A low price, on the other hand, might either chill investment or lead the firm to initiate a strenuous legal attack on the agreement if exercised. The need for a nondistorting means of transferring specialized assets from predecessor to successor firms is at any rate slight, because private ownership of nonredeployable assets offers no significant advantages over state ownership. See infra text accompanying notes 101-02. However, because state ownership does entail some efficiency costs, see infra note 100 , private ownership of readily redeployable assets is desirable.

100. Bureaucratic delays can add years to the process of prison construction. The state also may be slower to adopt new prison technologies. The firm as tenant will undertake only the modifications that it expects to pay for themselves within the contract life.

101. Competing architects can consult with or merge with private prison managers to produce efficient designs. They will carefully educate the state on the comparison between the current incremental capital expenditure for the facility and the present value of the expected stream of later savings. This system will also preserve some innovation by the management firm, see supra note 100 , and the firm might propose more substantial changes, with the state undertaking part of the funding.

102. See Privatization of Corrections, supra note 1 , at 37-48 (discussing lease financing). In effect, the state would make these same lease/purchase payments, contained in the per diem price, to a management firm that owned its own facility. The key point is that the separate architectural and construction contracts are one-time affairs, wholly removed from decisions about operation, with no risk of a fundamental transformation. A similar effect might be achieved by means of a long term lease, unrelated to the management contract, of the facilities to the state by a private firm. 


\section{The Effects of Prison Characteristics on Monitoring}

Prison privatization is at a singular stage of development. During this buy-in period, public scrutiny is so keen that virtually any monitoring scheme will be sufficient to ensure prison quality. Moreover, private prison contracts have been confined almost exclusively to small county jails, alien deportation centers, and juvenile detention facilities. ${ }^{103}$ In these settings, both the weaknesses of administrative monitoring and some of the advantages of the fine system will be less apparent. It is in the next wave of privatization, when public curiosity has waned and private firms manage large, high security facilities for the confinement of traditional classes of offenders, ${ }^{104}$ that the fine system proposed here can do the most to reform prisons.

In describing the virtues of the fine system, this Note has treated prisons as if they were largely homogeneous. Such is not the case, of course; prisons differ in size, inmate sophistication, length of sentence, and seriousness of inmate offense, to name but a few variables. ${ }^{105}$ The effectiveness of any monitoring scheme will depend on the characteristics of the prison monitored.

\section{A. Number of Inmates}

The fine system relies on a relationship between behavior on the part of the jailer and a resultant set of outcomes, outcomes that are distributed in some fashion about a mean. If the population served by the firm, either at one institution or many, is large, the chances are much greater that the observed characteristics of the incarcerated population will faithfully reflect the tendencies of the jailer's policies, and thus that the fine system's rewards and punishments will be accurate. ${ }^{108}$

103. See supra note 1. Two reasons for this path of development suggest themselves. First, these facilities require fewer specialized assets. Firms can thus exit with minimal loss of capital, and the states are not forced to pay a risk premium. Second, the long run monitoring difficulties associated with these facilities, as will be described, have obvious, if not admirable, attractions for the firm and the state.

104. Such facilities are in the offing. See, e.g., Wash. Post, Sept. 22, 1985, at F1, col. 4; see also Woolley, Prisons for Profit: Policy Considerations for Government Officials, 90 Dick. L. REv. 307, 308-09 (1985) (describing recent privatization proposals).

105. Notoriety of the facility is another particularly important quality in the analysis of private prisons. All private prisons are notorious now and virtually monitor themselves. Monitoring difficulties can be expected to increase as time passes. Other factors include the homogeneity of the inmate population, personnel and physical plant requirements, and the aggressiveness of judicial review. Ringing the changes on all these variables is beyond the scope of this Note. The purpose of this discussion is merely to indicate how different prison settings may inhibit or enhance monitoring.

106. A large facility is also more likely to attract the press scrutiny on which the fine system relies. Researchers seek large samples to reduce statistical error, reporters recognize the greater likelihood of finding a story in a place where there are more stories to tell, and prison projects and monitoring groups prefer to concentrate their resources where the greatest number of inmates can be helped (there being economies of scale in some reforms). Particularly after private prisons have be- 
On the other hand, the costs of administrative monitoring will rise as prison population rises. The increased number of observations will not mean greater statistical reliability, as it does under the fine system, in which violations are easily detectable, but simply a need for more monitor hours. Monitoring costs will thus rise in proportion to population, and they might even have a positive second derivative for relevant population sizes, given the complexities of coordination and control that can arise as the structure to be monitored grows more complicated.

\section{B. Sophistication of Inmates}

Youthful inmates, the mentally ill, and foreign detainees with scant knowledge of our legal culture are placed at a disadvantage under any system of monitoring that relies on their observations and initiative. These prisoners and detainees will not be as well equipped as more sophisticated inmates to observe and coherently convey to the representatives of the public the more subtle and fleeting harms that might occur, and they will be much less likely to seek out appropriate persons to whom they can report abuses.

Any system of monitoring will perform better as the sophistication of prison inmates increases, but the fine system is likely to be less affected than administrative monitoring by changes in prisoner savvy. ${ }^{107}$ The fine system is based on simple, easily detectable events and will perform well even if inmates are largely passive.

\section{Length of Sentence}

A transient prison population can present particular monitoring difficulties. If the average sojourn in a facility is only a few weeks, the fine system can become virtually useless in some respects and drastically more expensive to administer in others. It seems fair to assume that no existing or immediately foreseeable rehabilitation techniques will generate measurable progress in such a short span of time. Regardless of its efforts, the firm will not be able to earn bonuses for reducing recidivism. Hence, it will cease squandering resources trying to do so. An important benefit of the fine system, the incentive to rehabilitate, and an important deterrent, a general fine triggered by the cumulation of many degrading but not directly dangerous practices, will be lost. Furthermore, fines for deaths,

\footnotetext{
come more commonplace, small private facilities may not receive sufficient press attention.

107. Traditional monitoring would seem not to involve prisoner initiative at all, but to rely on the observations of the administrative monitor. In practice, however, a crucial element of traditional monitoring over the past twenty years has been judicial oversight, an enterprise requiring not only lucidity on the part of prisoners, but often sufficient knowledge of the legal regime to allow the prisoners to know that a legal remedy exists.
} 
designed to prevent nonviolent endangerment of health by giving incentives to promote hygiene and to provide adequate nutrition and medical care, would lose much of their worth. ${ }^{108}$ First, even fairly egregious practices, if inflicted on a given inmate for only a few weeks, may produce no harm sufficient to trigger a fine. Second, even if a fine triggering event occurs, it is likely to do so only after release. The problem of hidden delivery is thus exacerbated in this setting. ${ }^{109}$

An obvious response to these difficulties is to deem the firm responsible for the inmate for some period after release, or until reincarceration, at which time it would in effect pay off its obligations by means of the recidivism fine. This Note adopts that approach with respect to recidivism in order to create an incentive in some entity to promote rehabilitation. ${ }^{\mathbf{1 1 0}}$ However, a similar expedient of extending the firm's responsibility for the physical well-being of inmates beyond the date of release would be more costly and less effective than the recidivism proposal. More detailed records, of a type not now kept, would be needed. Released inmates would have to be actively monitored; in contrast to the recidivism area, one cannot simply wait for their return to a system where their presence will be reported. Even more important is the impossibility of any effective control by the firm of the many variables that might bring about death or disease. ${ }^{111}$ There is no reason to charge the firm with extending lifespans in general or to expect the firm to succeed in doing so. In contrast, the firm may be in an excellent position to aid rehabilitation.

\section{Seriousness of Offense}

Many prison characteristics are interrelated, and the heinousness of a prisoner's crime will vary with the length of sentence, with the security level and hence the need for specialized assets, and with prisoner sophisti-

108. Fines for violently inflicted harms and for deaths flowing from those harms would continue to deter such abuses.

109. These weaknesses in the fine system are compounded by likely breakdowns in the secondary systems of press access and litigation. The fleeting nature of the abuses any given inmate suffers may lead that prisoner to accept the indignity stoically. Short term prisoners will also tend to be less sophisticated in the ways of prison life and therefore less likely to recognize and report problems. See Note, supra note 11 , at 1079 n.88 (short term prisoners have neither interest in change nor power to effect it). As a consequence, members of the press may never learn of the abuses, or the relatively niggling nature of the individual wrongs may lead them to determine that there can be little lasting public interest in such offenses. Furthermore, causes of action may never accrue in an environment so much in flux, or the glacial progress of judicial review may continually frustrate the successful prosecution of suits for small and relatively ancient wrongs. In such a setting, it will be easy for the entrepreneur to achieve cost savings by cutting small corners at the expense of societal preferences.

110. See supra note 54.

111. Compare the strict liability proposed for deaths during incarceration, when the firm can control many of the relevant variables. 
cation. But by styling an offense "serious," society means above all that societal disapprobation is great.

The traditional system of incarceration responds to a serious crime by devoting society's resources to increasing punishment and incapacitation, but curiously devotes no additional resources to rehabilitation of those whose reform would be most valued by society. The fine system offers a means of correcting that imbalance by increasing the fine/bonus for recidivism. ${ }^{112}$

\section{E. The Next Wave of Privatization}

The advantages of the fine system will thus become more pronounced as prison privatization becomes commonplace and expands beyond the specialized sorts of facilities now in private hands. Because small facilities generate fewer incidents to be observed, an administrative system-which relies primarily on direct oversight, actually seeing that each cell or meal is up to standard-can give fairly complete coverage. The fine system's reliance on statistical aggregates and on the creation of different incentives to monitor behavior confers no great benefit here. Moreover, these facilities are sufficiently notorious now to ensure adequate public scrutiny, thwarting both capture and sloth on the part of monitors; the prison firms' efforts to buy into the market guarantee that they will make needed information available.

The prisoners incarcerated in these facilities will tend to be less sophisticated, but the extreme difficulty of obtaining judicial review under any monitoring system when the term of imprisonment spans only a few months will combine with aggressive press scrutiny (in the short run) to limit the importance of the inmates' lack of shrewdness. Certainly illegal aliens, and perhaps other groups currently housed in private prisons, such as short term inmates in county jails, arouse little societal concern with rehabilitation. It follows that the loss of the fine system's incentive for rehabilitation is of little moment. The transience of the population of these facilities means that health and hygiene may be better protected by administrative monitoring, because of the costs of internalizing to the firm the benefits of improvement. Finally, because of the small capital outlays involved to date, entrenchment is not a threat. Traditional monitoring techniques can be adequate under such circumstances.

Reliance on administrative monitoring will, however, become increas-

112. Incapacitation seems a rather expensive vehicle for specific deterrence, with costs beginning at $\$ 20,000-30,000$ per prisoner per year, PRIVatization of CoRRECTIONS, supra note 1 , at 68 , an amount large enough to turn every criminal into a middle class burgher, but for the horrible incentive effects of that policy. Given that figure, ample funds could be made available for successful rehabilitation that could replace incapacitation. 
ingly unacceptable as privatization flourishes. A monitoring technique that is undaunted by large numbers, that is resistant to capture, that will generate sustained interest in the prison system, and that can combat the effects of entrenchment is needed. This Note's fine system meets those criteria and goes on to offer the potential for improved conditions and rehabilitation efforts. Adopting a radically different monitoring technique at the same time that prison privatization is beginning in earnest seems a very bold step politically, but the foregoing analysis suggests that the fine system will be the best, and may be the only satisfactory, means of monitoring large private facilities in the long run.

\section{Conclusion}

It is appropriate to be skeptical of the burgeoning growth of private prisons. The importance of imprisonment to our system of justice, the difficulty of observing the delivery of prison services, and the typical arrangement of prisons as monopolies combine with the profit motive to create the potential for failure. Private prisons present a chance for a radical breakthrough in corrections, however. If the state takes the steps described herein to preserve competition, firms' responsiveness to the profit incentive, the very factor that generates monitoring problems, can allow society to structure precise incentives for prison operation. By setting goals instead of operating standards, the fine system encourages innovation and reduces the need for centralized direction of prisons. In combination with press access, the fine system addresses prison failures before they reach the magnitude of Eighth Amendment violation, thereby obviating both the expense and delay of litigation and the interim suffering preceding the accrual of a cause of action. The proposed scheme also creates incentives for the firm to consider itself in the business of long range treatment, not mere warehousing. By enlisting private motives in public service, the system provides effective monitoring at a negligible public cost. Furthermore, the proposed system provides an effective means of aiding the formation, determination, and implementation of societal preferences. In particular, the system is useful in implementing judicial decrees. This important element of societal preferences regarding prisons has not been given full effect in the past, and the fine system can remedy that fault.

As private prisons become commonplace, the need for a mechanism that can effectively monitor all such facilities in the long run grows increasingly acute. Harnessing the potential of private prisons for the reform of corrections would meet that need and represent an extremely significant step forward in the effort to improve the prison system. 